\title{
Arctic marine climate of the early nineteenth century
}

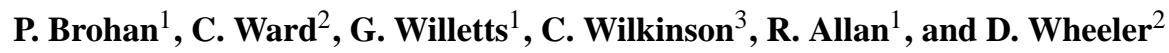 \\ ${ }^{1}$ Met Office Hadley Centre, Exeter, UK \\ ${ }^{2}$ Sunderland University, Sunderland, UK \\ ${ }^{3}$ University of East Anglia, Norwich, UK
}

Received: 14 January 2010 - Published in Clim. Past Discuss.: 2 February 2010

Revised: 6 May 2010 - Accepted: 10 May 2010 - Published: 21 May 2010

\begin{abstract}
The climate of the early nineteenth century is likely to have been significantly cooler than that of today, as it was a period of low solar activity (the Dalton minimum) and followed a series of large volcanic eruptions. Proxy reconstructions of the temperature of the period do not agree well on the size of the temperature change, so other observational records from the period are particularly valuable. Weather observations have been extracted from the reports of the noted whaling captain William Scoresby Jr., and from the records of a series of Royal Navy expeditions to the Arctic, preserved in the UK National Archives. They demonstrate that marine climate in 1810-1825 was marked by consistently cold summers, with abundant sea-ice. But although the period was significantly colder than the modern average, there was considerable variability: in the Greenland Sea the summers following the Tambora eruption (1816 and 1817) were noticeably warmer, and had less sea-ice coverage, than the years immediately preceding them; and the sea-ice coverage in Lancaster Sound in 1819 and 1820 was low even by modern standards.
\end{abstract}

\section{Introduction}

Instrumental records that adequately reflect large-scale climate change go back only to about 1850 (Brohan et al., 2006; Allan and Ansell, 2006) when the first national meteorological services were founded and systematic data collection began. There are limited instrumental records going further back (Jones et al., 2003; Parker et al., 1992), but

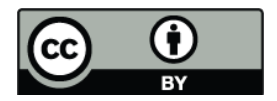

Correspondence to: $\mathrm{P}$. Brohan (philip.brohan@metoffice.gov.uk) for earlier periods we are mostly reliant on reconstructions from proxy observations (e.g. Jones et al., 2009) and noninstrumental observations (e.g. Wheeler et al., 2006). These reconstructions have large uncertainties, and the uncertainties are particularly large for the climate of the early 19th century (Jansen et al., 2007): when a combination of low solar activity (the Dalton minimum) and a series of large volcanic eruptions (notably Tambora in 1815) produced a cool period - but it is not known either how much the global mean temperature fell or how the climate changes varied around the world.

Quantifying the climate change of the early nineteenth century would be of value for climate model development and validation (Wagner and Zorita, 2005), and would help constrain proxy reconstructions of longer-term climate change. Such a quantification is possible because not only are there instrumental observations for the period (Wilson, 1985; Chenoweth, 1996, 1998, 2001; Harrington, 1992), but there is also potential to obtain new and additional observations from hitherto overlooked archive sources (Brohan et al., 2009). Although Arctic voyages in the early 19th century were not chiefly concerned with scientific investigation, many experiments were made and many valuable geomagnetic, meteorological and oceanographic data were collected.

A recent project (http://www.corral.org.uk) has catalogued and photographed the National Archive's collection of Royal Navy logbooks and journals of ships on voyages of exploration and discovery (catalogue section ADM55). Some of these logbooks contain instrumental weather observations, including those from a group of Arctic expeditions in the early nineteenth century, and some of these observations have been digitised as part of the project. Meanwhile, the international ACRE initiative (http://www.met-acre.org) has

Published by Copernicus Publications on behalf of the European Geosciences Union. 
augmented this data by digitising additional weather records from the published accounts of the same expeditions, and from the published reports of the noted whaling captain William Scoresby Junior (Jackson, 2003). These records, so far scarcely examined by climatologists, provide a unique insight into the climate of the Arctic of this period, long before regular observations were established - and it was the remarkable William Scoresby, a whaler with a scientific education, who first made systematic observations of the temperature of the region.

\section{William Scoresby}

William Scoresby Junior followed the example of his father (also William Scoresby) in becoming a successful and distinguished whaling captain; but he improved on his father's example by recording temperatures and weather encountered on his voyages, and publishing accounts of them. In each summer between 1810 and 1818 Scoresby was to be found, hunting whales, close to the edge of the ice in Fram Strait; and he published an account of positions, air temperature and pressure measurements in Scoresby Jr. (1820). In 1822 he extended his voyage to the east coast of Greenland, and again published an account in Scoresby Jr. (1823). The routes of these voyages are shown in Fig. 1.

Whales were easiest to find at the edge of the sea-ice, so the whaling fleet mostly operated as far north as it could get. Figure 2 compares Scoresby's measured temperatures with the range of values in a modern (1979-2004) air temperature climatology, and also shows the range of sea-ice expected at the position of the ship, from a modern sea-ice climatology for the same period (see Sect. 4). As the manner in which the temperature measurements was made is not known, it is possible that some differences between them and the climatology are an artifact of observational practice (Sect. 5.3), so a direct comparison is not appropriate. But, as the measurements are consistently from the same area, they can be used to investigate year-to-year changes.

In Fig. 2 the climatological temperatures and sea-ice (black lines) do not depend directly on the weather of the year in question, but only on the route of the ship: if the ship operates further north, the climatological temperatures along its route will reduce, and the climatological sea-ice along its route will increase. Because these ships are operating close to the sea-ice edge, a small change in latitude will have a much bigger effect on sea-ice than temperature. So an increase in the observed temperatures with respect to the climatology is a direct indicator of a warm year, and in such a warm year the ship will be operating further north than usual and the climatological sea-ice along the route of the ship will increase.

A remarkable feature of Scoresby's observations is that the summer of 1816 (the "year without a summer" following the Tambora eruption) was unusually warm in the Green-
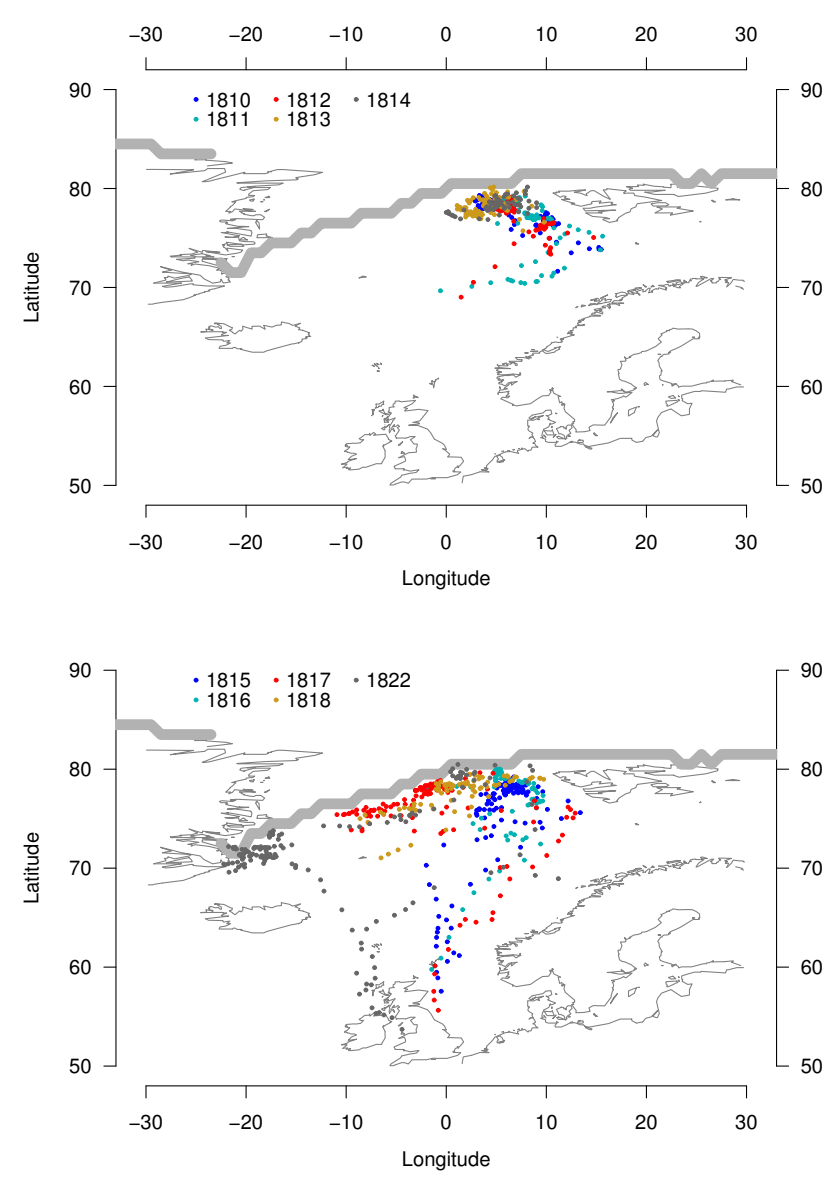

Fig. 1. Routes of William Scoresby's whaling voyages - split into two panels to avoid muddying the figure. The broad grey line is the September sea-ice edge from Rayner et al. (2003), median value over 1979-2004.

land sea; as was the following summer (Fig. 2). Writing to Sir Joseph Banks, president of the Royal Society, William Scoresby stated: "I observed on my last voyage (1817) about 2000 square leagues, (18000 square miles) of the surface of the Greenland seas, included between the parallels of $74^{\circ}$ and $80^{\circ}$, perfectly void of ice, all of which disappeared within the last two years". (Barrow, 1846). This combination of a clear statement from an experienced observer, and instrumental observations of air temperature which indicate the same changes, makes the Scoresby papers a compelling and precise source of information on climate variability.

\section{Naval expeditions}

In addition to the interest in the region from the whaling and economic point-of-view, the British Government, and institutions such as the Royal Society, were keen to sponsor more ambitious scientifically and politically driven Arctic voyages. The hazards of such voyages were not to be taken lightly, but considerable rewards were offered: an Act 
of Parliament provided a reward of $£ 5000$ to anyone able to penetrate beyond $89^{\circ}$ north, and $£ 20000$ to any mariner who could discover a route from the Atlantic to the Pacific in the Northern Hemisphere - the fabled "Northwest Passage". Unfortunately for the government, this offer was not taken up seriously despite the fabulous sums on offer: the Greenland whaling ships were not insured to operate outside of the normal fishing grounds, and the ships' masters had to take an oath on each voyage that they would not profit from any activity other than fishing (Barrington, 1818). So the British Government found themselves having to call on the Royal Navy.

At the turn of the nineteenth century, the most recent official expedition was that led by Constantine Phipps in 1773 (Phipps, 1775): Daines Barrington, a prominent member of the Royal Society, had proposed the voyage, and the Admiralty provided and equipped HMS Racehorse and HMS Carcass - with orders to approach the Pole along the longitude of Greenwich. The two ships had managed to reach only $80.6^{\circ}$ North in longitude $2.03^{\circ}$ East. Fresh activity was spurred in 1818 by the reports of changed ice conditions both in the Arctic and at lower latitudes: as well as Scoresby's findings, ships sailing to Halifax and Newfoundland in 18151817 were reporting sightings of "ice islands" as far south as the 40th parallel. At the same period, whaling ships in the Davis strait reported an unusual number of icebergs and floes drifting southward (Barrington, 1818). The possibility of a clear northern passage to the Pacific could not be ignored, and two new naval expeditions set out in 1818; to be followed by several others in the years following.

Weather observations have been digitised from five of these expeditions (Table 1) all dating from between 1818 and 1825, and covering the Far North Atlantic and Canadian Arctic (Fig. 3). Some of these logbook records have been previously recognised as a valuable source of climate data (Ward and Dowdeswell, 2006). The air temperature measurements made while the ships were overwintering at fixed locations have been extracted and analysed by Przybylak and Vizi (2005) and Przybylak et al. (2009). But the ships also measured air pressure, sea temperature, wind speed and direction, and sometimes humidity; and observations were made while the ships were at sea as well as when in winter harbour.

\subsection{HMS Dorothea, 1818}

According to the instructions issued to Captain David Buchan of HMS Dorothea in 1818, "the passage between the Atlantic and the Pacific is the main object of your mission". Buchan's instructions were quite specific. He was to sail between Greenland and Spitzbergen - the seas around the latter having been generally free of ice as far as $84^{\circ} \mathrm{N} \ldots$ "there is reason to expect that the sea may continue still more open northward, ... In this event you will steer due north ... to reach the North Pole. ... on leaving the Pole, you will
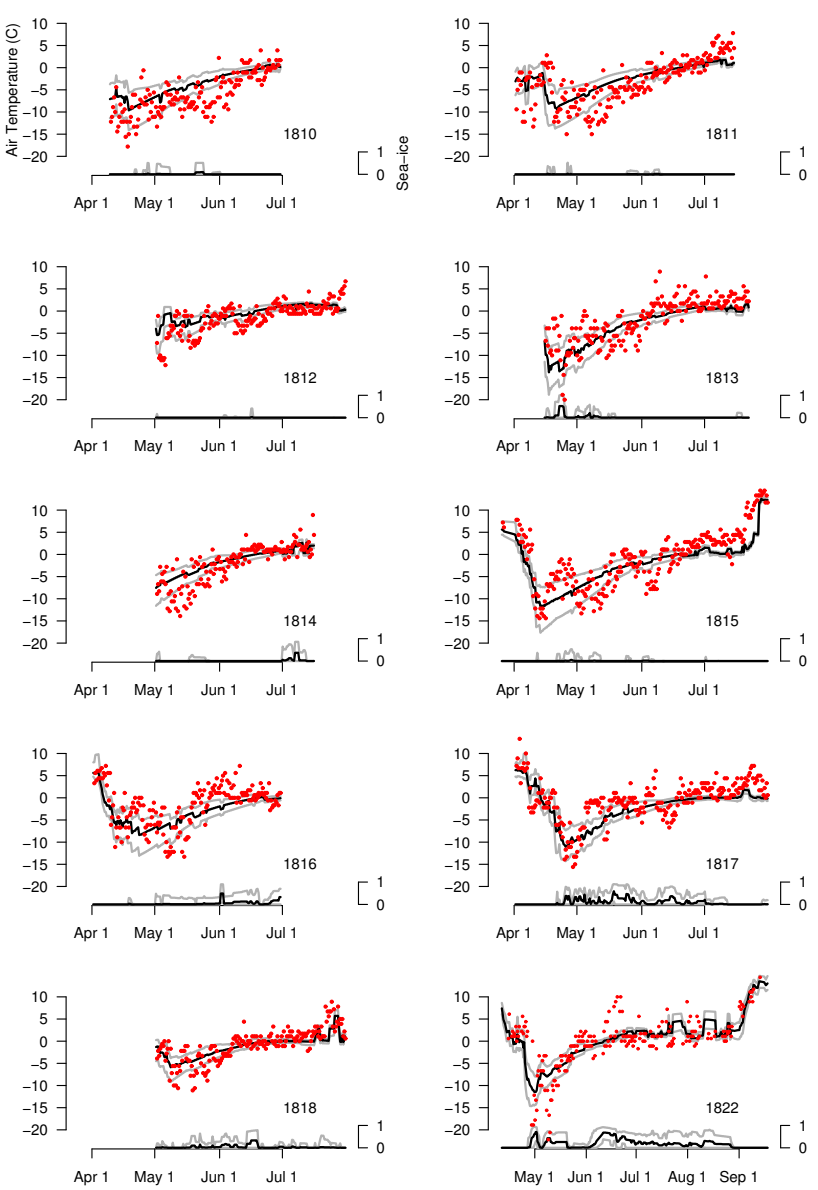

Fig. 2. Weather observations from William Scoresby's whaling voyages, air temperatures from each of 10 seasons compared with modern values. The red points are the observations, the black and grey lines are the mean, max and min values from modern datasets (monthly averages interpolated to daily, 1979-2004; AT from Rigor et al., 2000, sea-ice from Rayner et al., 2003).

endeavour to shape a course direct to Behring's [sic] Strait" (Beechey, 1843). In the event of obstruction by land or ice, Buchan was directed to pass between Greenland and the east coast of America, into Baffin's Bay, and then to the Davis Strait and home. He was accompanied by HMS Trent, commanded by John Franklin. In the event they failed to penetrate the pack ice in Fram Strait, spending only one summer in the Arctic.

Records of the expedition include a logbook containing the Dorothea's positions (Bruce, 1818, see Fig. 3), and another containing observations of pressure, air temperature, humidity, wind speed and direction (Morell, 1818) (Fig. 4).

\subsection{HMS Isabella, 1818}

A simultaneous, sister expedition was led by John Ross in HMS Isabella; in company with HMS Alexander commanded by William Parry. Ross had the same aim - Buchan's 
Table 1. Expeditions from which observations were digitised.

\begin{tabular}{llll}
\hline Date & Expedition Leader & Ships & Expedition aim \\
\hline 1818 & John Ross & Isabella and Alexander & Pacific via Baffin Bay and North-West Passage \\
1818 & David Buchan & Dorothea and Trent & Pacific via Fram Strait and North Pole \\
$1819-20$ & William Parry & Hecla and Griper & Northwest Passage via Lancaster sound \\
$1821-23$ & William Parry & Fury and Hecla & Northwest Passage via Hudson's Bay \\
$1824-25$ & William Parry & Fury and Hecla & Northwest Passage via Lancaster sound \\
\hline
\end{tabular}

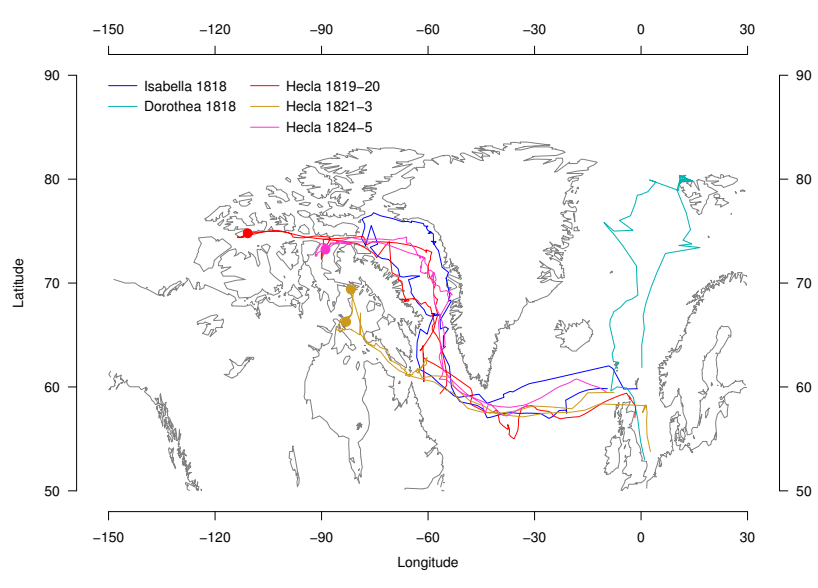

Fig. 3. Routes of the Royal Navy expeditions providing new observations. Filled circles mark overwintering sites.

instructions stated "you are to fix with Captain Ross, to whom the other expedition is entrusted, upon a rendezvous in the Pacific" (Beechey, 1843) - but Ross was instructed to seek a Northwest Passage via Baffin Bay. In the event they turned back at the entrance to Lancaster Sound, spending only one summer in the Arctic. The route of the expedition is documented in the Isabella's deck log (Ross, 1818, see Fig. 3), and the ship's meteorological logbook (Robertson, 1818) contains instrumental observations of sea temperature, air temperature and pressure, supplemented by observations of wind speed and direction (Fig. 5).

\subsection{HMS Hecla, 1819-1820}

William Parry was not impressed by Ross' decision not to venture down Lancaster Sound, and in 1819 he was appointed to the command of a follow-up expedition. Parry commanded HMS Hecla, and was accompanied by HMS Griper, commanded by Matthew Liddon. They travelled through Baffin Bay and Lancaster Sound, reaching Melville Island, where they spent the winter before turning back. Several logs from this expedition are in the ADM55 collection; but the meteorological logbooks are not among them, so meteorological observations have been taken from a published account of the expedition instead (Parry, 1821). The meteo-

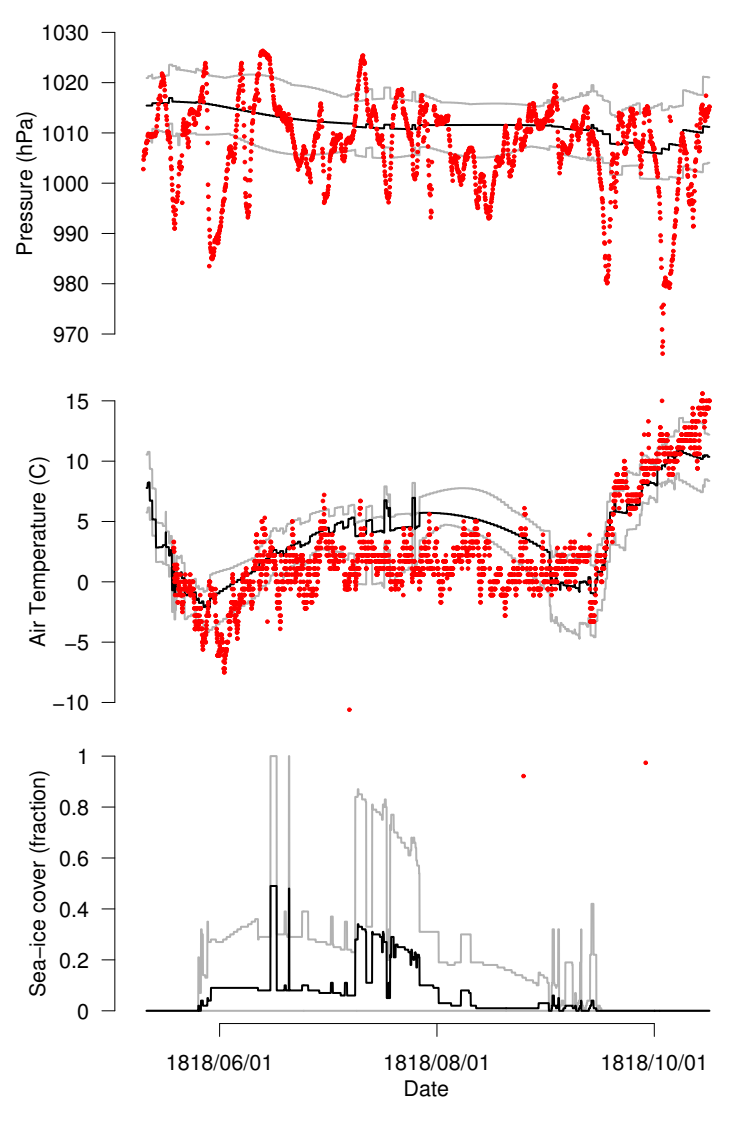

Fig. 4. Weather observations from HMS Dorothea, compared with modern values. The red points are the expedition's observations, the black and grey lines are the mean, max and min values from modern datasets (monthly averages interpolated to daily, 1979-2004; sea-ice from Rayner et al., 2003, AT from Rigor et al., 2000, and pressure from Allan and Ansell, 2006).

rological abstracts in Parry's account give the ship positions (Fig. 3), and daily maximum, minimum and mean air temperatures, sea temperatures and air pressures (Fig. 6).

\subsection{HMS Hecla, 1821-1823}

In 1821, Parry led a second second Northwest Passage expedition: commanding HMS Fury, and accompanied by HMS 

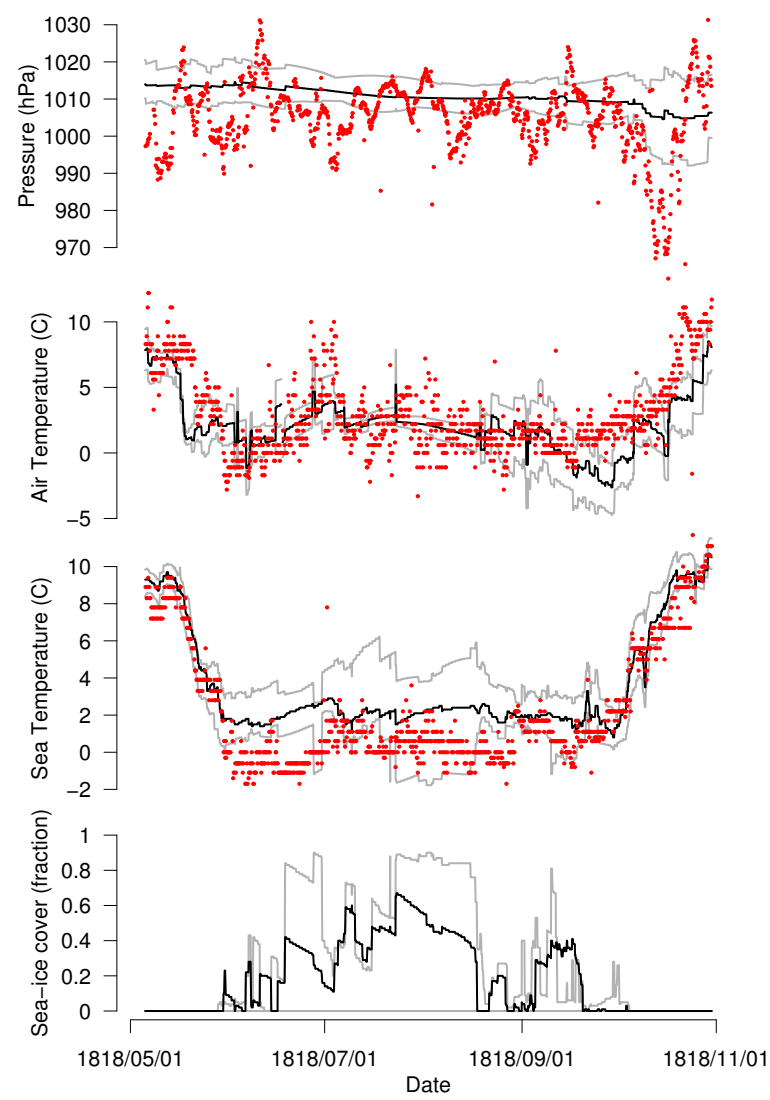

Fig. 5. Weather observations from HMS Isabella, compared with modern values. The red points are the expedition's observations, the black and grey lines are the mean, max and min values from modern datasets (monthly averages interpolated to daily, 1979-2004; SST and sea-ice from Rayner et al., 2003, AT from Rigor et al., 2000, and pressure from Allan and Ansell, 2006).

Hecla commanded by George Francis Lyon. They spent two winters in Foxe Basin, returning in the Autumn of 1823 after failing to penetrate the permanent ice in the strait between Foxe Basin and the Gulf of Boothia (named Fury and Hecla strait) (Parry, 1824 and Fig. 3). The ADM55 collection includes two meteorological logbooks for the Hecla (Various, 1821; Hoppner, 1823) providing air and sea temperatures, air pressures, and wind speed and direction (Fig. 7). The ship's position information (latitude and longitude) has been taken from Lyon (1823).

\subsection{HMS Fury and Hecla, 1824-1825}

HMS Fury and HMS Hecla also formed William Parry's third Northwest Passage expedition: Parry commanded the Hecla, and Henry Parkyns Hoppner the Fury. They followed a similar route to the 1819-1820 expedition, but got only as far as Port Bowen before having to stop for the winter (Parry, 1826). The Fury was damaged by ice and had to be abandoned, forcing the expedition to return in the sum-

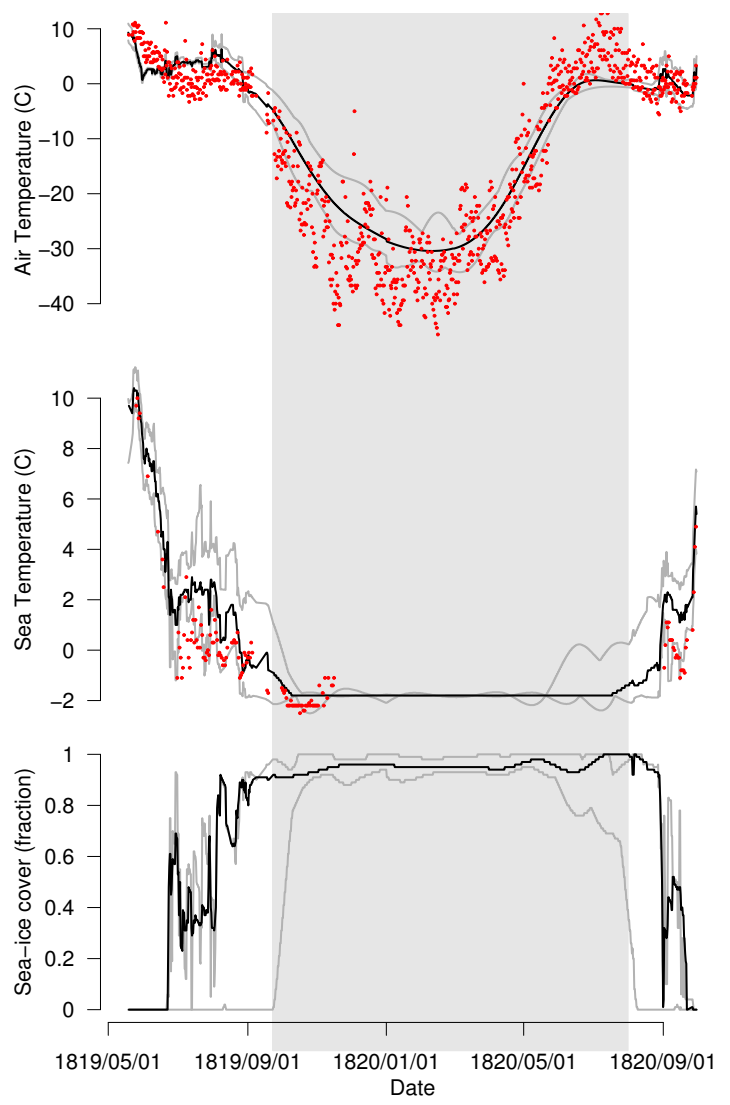

Fig. 6. Weather observations from HMS Hecla in 1819-1820, compared with modern values. The red points are the expedition's observations, the black and grey lines are the mean, max and min values from modern datasets (monthly averages interpolated to daily, 1979-2004; SST and sea-ice from Rayner et al., 2003, AT from Rigor et al., 2000, and pressure from Allan and Ansell, 2006). The grey band marks the period the expedition spent in winter harbour.

mer of 1825. Several logbooks from this expedition are in the ADM55 collection, but only Austin (1824) contained any meteorological observations, and these only covered the first part of the voyage. So again observations have been taken from a published account of the expedition (Parry, 1826) (Fig. 8).

\section{Comparing the expedition records with modern climatologies}

The Arctic is notably sensitive to changes in global climate, and one of the main interests in the observations is in comparisons with more recent climate. As the ships move about, it is impractical to compare their measurements to modern fixed station records - instead gridded climatologies have been used: 


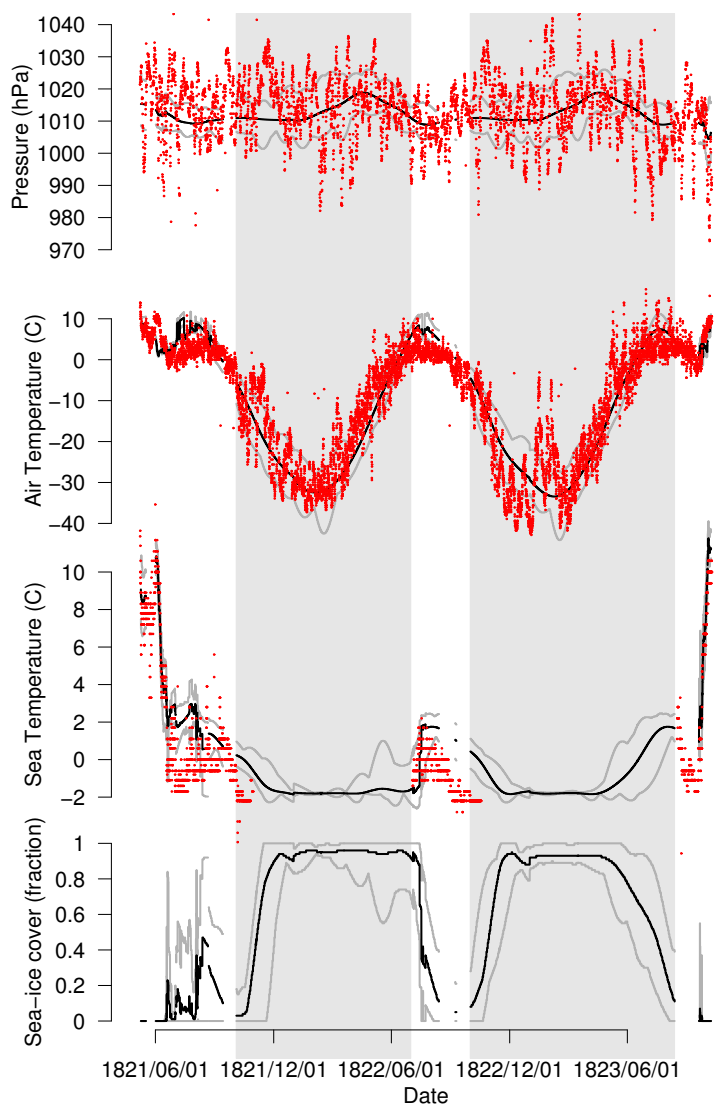

Fig. 7. Weather observations from HMS Hecla in 1821-1823, compared with modern values. The red points are the expedition's observations, the black and grey lines are the mean, max and min values from modern datasets (monthly averages interpolated to daily, 1979-2004; SST and sea-ice from Rayner et al., 2003, AT from Rigor et al., 2000, and pressure from Allan and Ansell, 2006). The grey bands mark the periods the expedition spent in winter harbours.

- Arctic air temperatures for 1979-2004 are provided by the POLES dataset (Rigor et al., 2000).

- Sea-temperature and sea-ice coverage for 1870 present are provided by the HadISST dataset (Rayner et al., 2003).

- Sea-level pressures for 1850-2004 are provided by the HadSLP2 dataset (Allan and Ansell, 2006).

For each observation, the gridded climatological value on the day of the measurement, at the location of the ship, has been extracted for each year from 1979-2004. The mean, maximum and minimum of the yearly values are shown in Figs. 5-8 along with the observed values. This indicates the range of observations to be expected from a ship reproducing the route of each expedition at the end of the twentieth century. As the gridded climatologies used are all monthly (interpolated to daily), the short-term variability (diurnal and

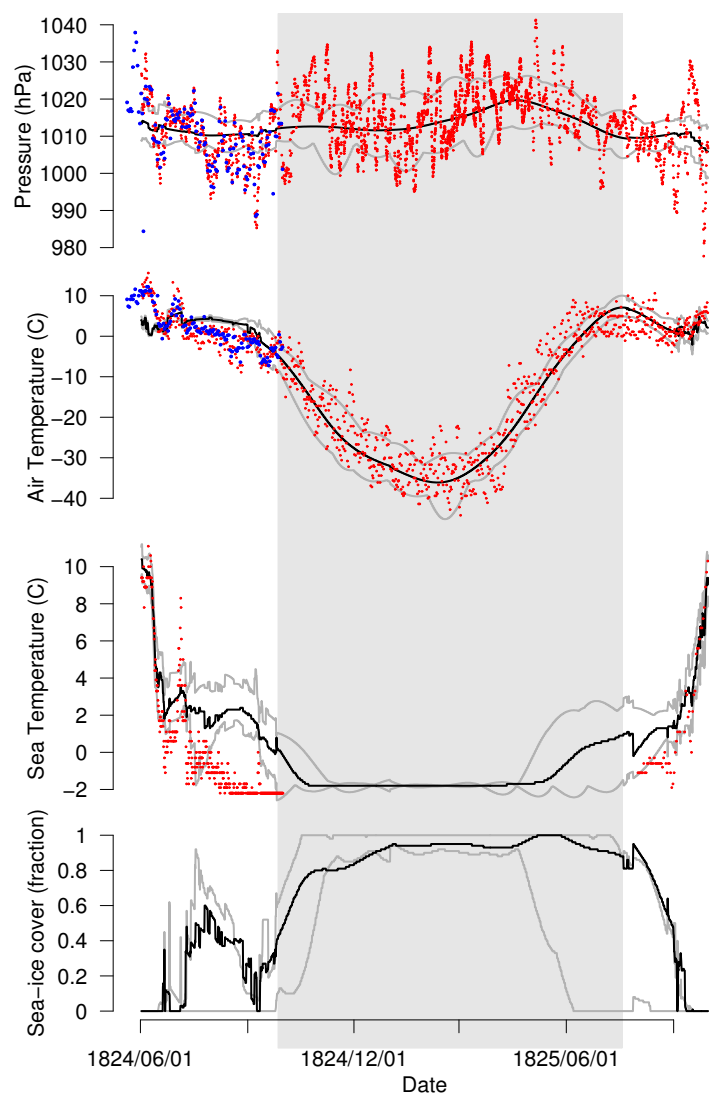

Fig. 8. Weather observations from HMS Hecla and Fury in 18241825 , compared with modern values. The red and blue points are the expedition's observations (red from Parry, 1826, and blue from Austin, 1824), the black and grey lines are the mean, max and min values from modern datasets (monthly averages interpolated to daily, 1979-2004; SST and sea-ice from Rayner et al., 2003, AT from Rigor et al., 2000, and pressure from Allan and Ansell, 2006). The grey band marks the period the expedition spent in winter harbour.

day-to-day changes) is not included - the range shown is of seasonal and interannual variability.

\section{Known biases}

The climatological comparisons show the observations to be expected using modern instruments and current observing practices. The expeditions were furnished with the best instruments of the time, and measurement errors are expected to be small (Ward and Dowdeswell, 2006), but changes in observing practices can be expected to produce some changes.

\subsection{Sea temperature}

Exactly how the sea-surface temperature measurements were made is not known in most cases, but they are likely to be measurements of samples taken in some form of bucket 
(Prestwich, 1874). The SST bias adjustments of Folland and Parker (1995) suggest that bucket measurement biases in the Arctic are likely to be small $\left(<0.1{ }^{\circ} \mathrm{C}\right)$.

\subsection{Air pressure}

The barometer readings have been corrected for latitude (gravity), but probably not for temperature, or for height of barometer above sea-level - neither the attached thermometer temperature, nor the barometer location on the ships are exactly known. It is likely that the barometers were kept in the captain's cabin, and so protected from the most extreme cold. A temperature variation of $20^{\circ} \mathrm{C}$ would give a barometric change of about $3.5 \mathrm{hPa}$, so the observations may have seasonally varying biases of about this amount. Previous work on marine pressure observations for this period has found that readings are sometimes too low by around $5 \mathrm{hPa}$ - the cause of this bias is still unknown (Allan and Ansell, 2006). The two 1818 expeditions in this dataset demonstrate this bias (Figs. 5 and 4), although the later expeditions do not.

\subsection{Air temperature}

The air temperature measurements are subject to a number of biases:

- Thermometer exposure: the modern Stevenson-type screen did not become common until well into the twentieth century. The measurements may be biased by inadequate shielding of the thermometer.

- Solar heating of the ship: the ship is likely to heat up in direct sunlight more than its surroundings.

- Direct heating from the ship: in the very cold conditions of the Arctic winter, the interiors of the ships were heated by coal fires. This was observed to bias the thermometers on deck.

- As some of the measured temperatures are below the freezing point of mercury $\left(-39^{\circ} \mathrm{C}\right)$, some of the measurements must have been made using less-accurate alcohol thermometers (Ward and Dowdeswell, 2006). It is not known which thermometers were used to provide the reported temperatures.

The officers and scientists making the observations were aware of these problems and took care to minimise and understand them. Parry noted that during the winter of 1819-1820, the ship's deck thermometers (which provide the records analysed here) were around 2 to $5^{\circ} \mathrm{F}$ ( 1 to $2^{\circ} \mathrm{C}$ ) higher than measurements on shore. He attributed this difference to direct heating - though subsequent expeditions did not reproduce this effect (Ward and Dowdeswell, 2006). Chenoweth (2000) investigated air temperature measurement biases in early 19th century marine observations and found ship-specific constant biases between $-1.76{ }^{\circ} \mathrm{C}$ and $1.74{ }^{\circ} \mathrm{C}$, and solar heating biases less than $1{ }^{\circ} \mathrm{C}$ even in the tropics. As direct solar radiation is much lower in the Arctic, such biases will be even smaller for these observations. The quality of the instruments used, and the care in taking the observations, is likely to be higher for the observations analysed here than those used in Chenoweth (2000), at least for the naval expeditions (Ward and Dowdeswell, 2006), the observations are therefore unlikely to be seriously in error.

\subsection{Sea-ice}

The meteorological logbooks do not contain systematic, quantitative statements about sea-ice; but it is possible to infer the coverage from the movements of the ships. Because the ships were trying to make their way through iceblocked seas, they were operating for much of the time right at the edge of navigable ice. In particular the ships were surrounded by solid ice throughout their periods in winter harbour - they generally had to resort to saws or explosives to break up the ice to get into and out of winter harbour locations (Parry, 1821, 1824, 1826). Sea-surface temperatures also give information on sea-ice: SSTs of less than about $2{ }^{\circ} \mathrm{C}$ are generally indicative of ice cover, and by the time the $\mathrm{SST}$ reaches $-1.8^{\circ} \mathrm{C}$ (the freezing point of seawater) the ice cover is complete.

\section{Inferences about climate of the period}

\subsection{Greenland Sea - summers of 1810-1817}

The biases in Scoresby's air temperature measurements are not known exactly, but it is likely that his measurements are too high rather than too low. So for the years 1810-1815, where the reported temperatures are typically comparable to or lower than modern climatology, it is likely that the climate was somewhat colder than in 1979-2004. This is supported by the observation that he was operating at latitudes where sea-ice was rarely or never seen during 1979-2004, in spite of habitually working close to the ice edge.

In 1816 and 1817, the temperatures rose significantly, and the zone of operation moved north (presumably along with the sea-ice).

\subsection{Baffin Bay - summer 1818}

At the beginning and end of this voyage, when the ship was crossing the relatively warm North Atlantic, the observed air temperatures were slightly above the modern average, and the observed SSTs slightly below (Fig. 5). When the ship reached the modern-day sea-ice edge in the Labrador Sea the observed temperatures fell, both in absolute terms and relative to the modern values, and they stayed low throughout the circuit of Baffin Bay. The 1979-2004 sea ice coverage in the region is very variable, and it is likely that in 1818 was 
on the high side of the modern range, but not exceptionally so, except perhaps in June, when very cold conditions were experienced.

\subsection{Fram Strait - summer 1818}

The Dorothea (Fig. 4) saw falls in absolute and relative temperatures when it reached the modern sea-ice edge in Fram Strait. The modern sea-ice coverage at the latitudes the expedition reached is modest (none in warm years), and this is confirmed by Scoresby's observations in almost the same place. So, as in Baffin Bay the same year, the summer of 1818 was somewhat colder than in 1979-2004, with more sea-ice than usual.

\subsection{Lancaster Sound and Melville Island - 1818-1819}

The most immediately striking point in Fig. 6 is (as already noted by Przybylak and Vizi, 2005) the very low winter temperatures. Even more remarkable, however, are the sea-ice conditions: the synchronous drop in SST in the observations and the climatology in summer 1819 show that the sea-ice edge in the Labrador sea was in much the same place in 1819 as in the modern day, but the late freezing of the sea ice around Melville Island is very unusual by modern standards, as is the early break-up of the ice the following year (note the anomalously warm period in the early summer of 1820). In all but the lowest sea-ice years in the 1979-2004 period the sea-ice around Melville Island persisted throughout the year.

\subsection{Foxe Basin - 1821-1823}

The 2.5-year record for the expedition to Foxe Basin (Fig. 7) shows consistently cold summers (low air and sea temperature), but not the very cold winters seen on the 1819-1820 expedition. The sea-ice conditions are also consistent with summers being significantly colder than the modern range. In both 1821 and 1822 the sea froze completely weeks before it did so in any year in the modern range, and in 1823 the thaw was similarly delayed.

\subsection{Greenland Sea - summer of 1822}

On the other side of Greenland, in the summer of 1822 Scoresby was finding very different conditions in the Greenland Sea, where a low sea-ice year allowed him to venture unusually far north.

\subsection{Baffin Bay and Port Bowen - 1824-1825}

The last expedition (Fig. 8) showed the same pattern as that of 1821-1823: cold summers (in both air and sea temperatures) and early onset of completely frozen sea. Again winter temperatures are unexceptional.

\section{Conclusions}

The logs of whaling voyages and Royal Navy expeditions in the early nineteenth century offer a valuable source of information on the Arctic climate of the period. The observations are regularly and carefully made, and the combination of air temperature, sea surface temperature, and ship movement information allow confident inferences to be made about climate change in spite of uncertainties about observing methods and instruments.

Marine Arctic climate in 1810-1825 (compared to 19792004) was marked by consistently cold summers, with a lot of sea-ice. But although the period was significantly colder than the modern average, there was a lot of variability. In the Greenland Sea, the summers following the Tambora eruption (1816 and 1817) were noticeably warmer and had lower seaice coverage than the years immediately preceding them, and the sea-ice in Lancaster Sound in 1819 and 1820 was low even by modern standards.

Acknowledgement. This work was funded by the Joint Information Systems Committee through the CORRAL project (Colonial Registers and Royal Navy Logbooks). PB and RA were also supported by the Joint DECC and Defra Integrated Climate Programme, DECC/Defra (GA01101), and RA also by the Queensland Climate Change Centre of Excellence (QCCCE).

Edited by: J. Guiot

\section{References}

Allan, R. J. and Ansell, T. J.: A new globally complete monthly historical gridded mean sea level pressure data set (HadSLP2): 1850-2003, J. Climate, 19, 5816-5842, 2006.

Austin, H. F.: A log of the proceedings on board H. M. S. Fury, online available at: http://badc.nerc.ac.uk/cgi-bin/corral/ view_images $/ \mathrm{a}=55 / \mathrm{p}=4 / \mathrm{l}=56 / \mathrm{v}=1,1824$.

Barrington, D.: The Possibility of Approaching the North Pole Asserted, James Eastburn \& co., online available at: http://books. google.co.uk/books?id=rVIQAAAAYAAJ, 1818.

Barrow, J.: Voyages of Discovery and Research within the Arctic Regions from the year 1818 to the present time, John Murray, online available at: http://books.google.co.uk/books?id=E OfAAAAMAAJ, 1846

Beechey, F. W.: A Voyage of Discovery towards the North Pole, performed in His Majesty's ships Dorothea and Trent, under the command of Captain David Buchan, R.N.; 1818, Richard Bentley, online available at: http://books.google.com/books?id= MKwNAAAAQAAJ, 1843.

Brohan, P., Kennedy, J., Harris, I., Tett, S. F. B., and Jones, P. D.: Uncertainty Estimates in Regional and Global Observed Temperature Changes: a new dataset from 1850, J. Geophys. Res., 111, D12106, doi:10.1029/2005JD006548, 2006.

Brohan, P., Allan, R., Freeman, J. E., Waple, A., Wheeler, D., Wilkinson, C., and Woodruff, S.: Marine observations of old weather, B. Am. Meteorol. Soc., 90, 219-230, doi:10.1175/2008BAMS2522.1, 2009. 
Bruce, P.: Arctic regions log of ship Dorothy, online available at: http://badc.nerc.ac.uk/cgi-bin/corral/view_images/a=55/p=3/ $l=37 / v=1,1818$.

Chenoweth, M.: Ship's Logbooks and "The Year Without an Summer", B. Am. Meteorol. Soc., 77, 2077-2094, 1996.

Chenoweth, M.: The Early 19th Century Climate of the Bahamas and a Comparison with 20th Century Averages, Climatic Change, 40, 577-603, doi:10.1023/A:1005371320672, 1998.

Chenoweth, M.: A new methodology for Homogenization of 19th century marine air temperature data, J. Geophys. Res., 105, 29145-29154, 2000.

Chenoweth, M.: Two major volcanic cooling episodes derived from global marine air temperature, AD 1807-1827, J. Geophys. Res., 28, 2963-2966, doi:10.1029/2000GL012648, 2001.

Folland, C. K. and Parker, D. E.: Correction of instrumental biases in historical sea surface temperature data., Q. J. Roy. Meteorol. Soc., 121, 319-367, 1995.

Harrington, C. R. (ed.): The year without a summer?: world climate in 1816, Ottawa: Canadian Museum of Nature, 1992.

Hoppner, H. P.: Meteorological journal, H. M. S. Hecla, online available at: http://badc.nerc.ac.uk/cgi-bin/corral/view_images/ $\mathrm{p}=7 / 1=66,1823$.

Jackson, C. I.: The Arctic Whaling Journals of William Scoresby the Younger. Vol. 1, The Voyages of $1811 \mathrm{~m} 1812$ and 1813, Hakluyt Society, 2003.

Jansen, E., Overpeck, J., Briffa, K. R., Duplessy, J. C., Joos, F., Masson-Delmotte, V., Olago, D., Otto-Bliesner, B., Peltier, W. R., Rahmstorf, S., Ramesh, R., Raynaud, D., Rind, D., Solomina, O., Villalba, R., and Zhang, D.: PalaeoClimate, chap. 6 of Climate Change 2007: The Physical Science Basis. Contribution of Working Group I to the Fourth Assessment Report of the Intergovernmental Panel on Climate Change, edited by: Solomon, S., Qin, D., Manning, M., Marquis, M., Averyt, K. B., Tignor, M., Miller, H. L., and Chen, Z., Cambridge University Press, 433-497, 2007.

Jones, P. D., Briffa, K. R., and Osborn, T. J.: Changes in the Northern Hemisphere annual cycle: Implications for paleoclimatology?, J. Geophys. Res., 108(D18), 4588, doi:10.1029/ 2003JD003695, 2003.

Jones, P. D., Briffa, K. R., Osborn, T. J., Lough, J. M., van Ommen, T. D., Vinther, B. M., Luterbacher, J., Wahl, E. R., Zwiers, F. W., Mann, M. E., Schmidt, G. A., Ammann, C. M., Buckley, B. M., Cobb, K. M., Esper, J., Goose, H., Graham, N., Jansen, E., Kiefer, T., Kull, C., Kuttel, M., Mosley-Thompson, E., Overpeck, J. T., Riedwyl, N., Schulz, M., Tudhope, A. W., Villalba, R., Wanner, H., Wolff, E., and Xoplaki, E.: Highresolution palaeoclimatology of the last millennium: a review of current status and future prospects, Holocene, 19, 3-49, doi: 10.1177/0959683608098952, 2009.

Lyon, G. F.: Log of HMS Hecla, online available at: http:// badc.nerc.ac.uk/cgi-bin/corral/view_images/a=55/p=3/l=62/v=1, 1823.

Morell, A.: Log of the Dorothea, online available at: http://badc. nerc.ac.uk/cgi-bin/corral/view_images/a=55/l=36/p=1/, 1818 .

Parker, D. E., Legg, T. P., and Folland, C. K.: A new daily Central England Temperature series, Int. J. Climatol., 12, 317-342, 1992.

Parry, W. E.: Journal of a voyage for the discovery of a NorthWest Passage from the Atlantic to the Pacific, performed in the years 1819-20 in His Majesty's ships Hecla and Griper, under the orders of William Edward Parry, R.N., F.R.S, and commander of the expedition, John Murray, online available at: http://books. google.co.uk/books?id=f8VCAAAAYAAJ, 1821.

Parry, W. E.: Journal of a second voyage for the discovery of a North-West Passage from the Atlantic to the Pacific, performed in the years 1821-22-23 in His Majesty's ships Fury and Hecla, under the orders of William Edward Parry, R. N., F. R. S, and commander of the expedition, John Murray, online available at: http://books.google.co.uk/books?id=stoBAAAAYAAJ, 1824.

Parry, W. E.: Journal of a third voyage for the discovery of a NorthWest Passage from the Atlantic to the Pacific, performed in the years 1824-25 in His Majesty's ships Fury and Hecla, under the orders of William Edward Parry, R. N., F. R. S, and commander of the expedition, H. C. Cary and I. Lea, online available at: http: //books.google.co.uk/books?id=FYBLEp43pCwC, 1826.

Phipps, C. J.: A Voyage towards the North Pole undertaken by His Majesty's command 1773, Sleater, Williams, Wilson, Husband, Walker and Jenkin, online available at: http://books.google.co. uk/books?id=ZpMBAAAAYAAJ, 1775.

Prestwich, J.: Tables of Temperatures of the Sea at different Depths beneath the Surface, reduced and collated from the various observations made between the years 1749 and 1868, discussed, Philos. T. Roy. Soc. London, 165, 587-674, doi:10.1098/rstl.1875. 0021, 1874.

Przybylak, R. and Vizi, Z.: Air temperature changes in the Canadian Arctic from the early instrumental period to modern times, Int. J. Climatol., 25, 1507-1522, doi:10.1002/joc.1213, 2005.

Przybylak, R., Vizi, Z., and Wyszyński, P.: Air temperature changes in the Arctic from 1801 to 1920, Int. J. Climatol., 30(6), 791812, doi:10.1002/joc.1918, 2009.

Rayner, N. A., Parker, D. E., Horton, E. B., Folland, C. K., Alexander, L. V., Rowell, D. P., Kent, E. C., and Kaplan, A.: Global analyses of SST, sea ice and night marine air temperature since the late nineteenth century, J. Geophys. Res., 108(D14), 4407, doi:10.1029/2002JD002670, 2003.

Rigor, I. G., Colony, R. L., and Martin, S.: Variations in Surface Air Temperature Observations in the Arctic, 1979-97, J. Climate, 13, 896-914, 2000.

Robertson, W.: Meteorological log of HMS Isabella, online available at: http://badc.nerc.ac.uk/cgi-bin/corral/view_images/ $\mathrm{l}=082 / \mathrm{p}=1 /, 1818$.

Ross, J.: Log of HMS Isabella, online available at: http://badc.nerc. ac.uk/cgi-bin/corral/view_images/l=081/p=1/, 1818 .

Scoresby Jr., W.: An account of the Arctic Regions, with a History and Description of the Northern Whale-Fishery, Archibald Constable \&co., online available at: http://books.google.co.uk/ books?id=ObUUAAAAQAAJ, 1820.

Scoresby Jr., W.: Journal of a voyage to the Northern WhaleFishery, Archibald Constable \&co., online available at: http: //books.google.co.uk/books?id=DXg9AAAAYAAJ, 1823.

Various: Meteorological journal and abstract, made on board His Majesty's ship Hecla, by the officers of the watch, online available at: http://badc.nerc.ac.uk/cgi-bin/corral/view_images/a=55/ $\mathrm{p}=3 / \mathrm{l}=65 / \mathrm{v}=1,1821$.

Wagner, S. and Zorita, E.: The influence of volcanic, solar and $\mathrm{CO}_{2}$ forcing on the temperatures in the Dalton Minimum (17901830): a model study, Clim. Dynam., 25, 205-218, doi:10.107/ s00382-005-0029-0, 2005.

Ward, C. and Dowdeswell, J. A.: On the Meteorological Instru- 
ments and Observations Made during the 19th Century Exploration of the Canadian Northwest Passage, Arctic, Antarctic, and Alpine Research, 38, 454-464, 2006.

Wheeler, D., Herrera, R. G., Koek, F., Wilkinson, C., Konnen, G., del Rosario Prieto, M., Jones, P. D., and Casale, R.: CLIWOC, Climatological database for the world's oceans, European Commission, 2006.
Wilson, C.: The Little Ice Age on Eastern Hudson/James Bay: The Summer Weather and Climate at Great Whale, Fort George and Eastmain, 1814 to 1821, as Derived from Hudson's Bay Company Records., in: Climatic Change in Canada 5: Critical periods in Quaternary Climate History of Northern North America. edited by: Harrington, C., vol. 55 of Syllogeus, Ottawa: National Museums of Canada, 1985. 